\title{
Examination of Physical Fitness and Somatotype Features of Parkour Practitioners (Traceur) and Gymnasts in University Education
}

\author{
Sinan Seyhan ${ }^{1}$ \\ ${ }^{1}$ Faculty of Sport Sciences, Celal Bayar University, Manisa, Turkey \\ Correspondence: Sinan Seyhan, Faculty of Sport Sciences, Celal Bayar University, 45040 Manisa, Turkey. \\ E-mail: sinan.seyhan@cbu.edu.tr
}

Received: February 10, 2019

Accepted: March 5, 2019 Online Published: March 8, 2019

doi:10.5539/jel.v8n2p241

URL: https://doi.org/10.5539/jel.v8n2p241

\begin{abstract}
The purpose of this study was to examination the physical and anthropometric features of the traceurs with the gymnasts university education. The study was carried out with university students, male twelve volunteer participants (traceurs $=6$, gymnasts $=6$ ). The mean age of the traceurs was $18.67 \pm 1.03$ years, $172.67 \pm 3.78 \mathrm{~cm}$, body weight $62.5 \pm 8.94 \mathrm{~kg}$ and BMI was $20.98 \pm 2.97 \mathrm{~kg} / \mathrm{m}^{2}$; gymnasts was $19.33 \pm 1.21$ years, $175.83 \pm 6.18 \mathrm{~cm}$, body weight $65.17 \pm 8.06 \mathrm{~kg}$ and BMI was $21.11 \pm 2.67 \mathrm{~kg} / \mathrm{m}^{2}$. According to the data obtained from traceurs and gymnasts, the somatotype features of the athletes were endomorph (2.70 \pm 0.32$)$, mesomorph $(4.09 \pm 1.70)$ and

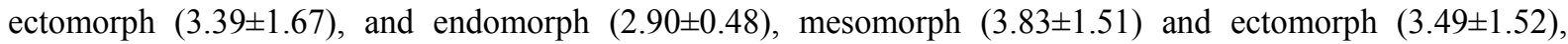
respectively. It can be said that the dominant somatotype structures between the groups and within the groups are mesomorphy and ectomorphy in the traceurs and gymnasts. When somatotype features were compared between groups, no significant difference was observed. It is noteworthy that both branches have similar body structures (mesomorphy and ectomorphy). In conclusion, learning of these body structure features that determine and affect the performance by coaches education of athletes that athletes will show that perform successfully only with appropriate body structures and coaches may enable the preparation of a better training program.
\end{abstract}

Keywords: parkour, gymnastics, somatotype

\section{Introduction}

The parkour is the abbreviation of a French word "parcours" and can be defined as a physical activity spreading from the back streets of Paris all over the world. Athletes, called traceurs, have to overcome all of the determined obstacles with their body structures, flexibilities, all other physical qualities such as running and jumping. Traceurs complete the course by making movements that strain themselves physically with these individual features. Parkour sport can be defined as the ability not only to move quickly in urban areas and in natural environments by using the physical qualities of the body, but also as the ability of traceurs known as parkour practitioners to overcome the obstacles they encounter by combining their self with the structural features of the city (Grospretre \& Lepers, 2016; Thomson, 2008). The special movements that form the basis of the parkour sport are based on the disciplines of running and jumping of sports branches such as gymnastics and athletics. For this reason, it is possible for them to be successful by fulfilling certain requirements of gymnastics and athletics branches in order to overcome urban and natural obstacles without any material requirement (Grospretre, Ufland, \& Jecker, 2018).

Body structure of the athletes can be expressed as the most important factor that make up the success with some basic performance features such as strength, endurance, flexibility and agility. In short, it is an important indicator of the performance, physical fitness and health of the athletes. A suitable body structure in terms of body shape and muscle mass contributes significantly to performance in many sports, especially in aesthetic sport. The physical fitness of the athletes allows them to perform all the movements required by the sports branch in which they are engaged. As the excessive fat tissue will bring an extra burden on the body against gravity during the jumps and take-offs, it may decrease the athlete's performance besides requiring extra energy (Kaynar, Seyhan, \& Bilici, 2018; Yıldız, 2018; Mala et al., 2015; Misigoj-Durakovic, 2012; Ozkan, Koklu, \& Ersoz, 2010).

It is known that somatotype structures, anthropometric and physical features of athletes who are interested in gymnastics sports, which is one of the branches with special technique applications and which requires a great 
number of jumps, are also different. As in all other sports branches, the successful performance of the athletes who are interested in the parkour and gymnastics branches is closely related to the sufficiently physical features required by these branches (Hume et al., 1993). These physical features are important determinants for the successful performance of athletes. When the literature is examined, unlike other sports branches, there are not many studies conducted on this sport. On the other hand, in many studies on different branches, it is stated that the anthropometric features of the athletes have to be appropriate at the level of fulfilling the requirements of the sports branch in which they are engaged. It was demonstrated in many studies that the positive effects of anthropometric features of athletes on their development levels and athletic performances are very important for success (Marta et al., 2013; Vila et al. 2009).

One important point that researches in sports science emphasize is that the body compositions of the athletes can increase the chances of sport-specific success. These characteristics may be different for each sport branch and the ability to be successful in the determination of their abilities is closely related to the consideration of these characteristics (Claessens et al., 1999). Body structure can vary in every person. The reason for this difference is genetics, nutrition, gender, age, and the changes in the body of the sports branch of which it is interested and environmental factors. Anthropometric measurements are needed to identify these differences. Anthropometric features, a design of biological variables related to sports performance. Therefore, knowing the anthropometric properties of athletes provides important information about health status, body structure and shape (Moreno, Moreno, \& Jaramillo, 2011; Munoz-Cachon et al., 2007). Physical appearance, body mass, shape and size of the body are very important for high performance in many sports branches. Athletes who have this awareness know that they need to routinely monitor their body composition throughout the season. The determination of the body structures of the athletes is not only related to the planning of the training levels or to reveal the physical exercise intensity. In addition to these goals, determination of nutritional status, monitoring of the patient until the treatment in diseases, growth and development, aging studies, and many other reasons require the identification body structure (Munoz-Cachon et al., 2007; Slater, O’Connor, \& Kerr, 2017; Ozer, 2009).

Sheldon classified the human body according to its structural features by forming an atlas (Sheldon, 1954). These classifications are in the form of mesomorph, ectomorph and endomorph. Lastly, Heath-Carter formulized these to determine the somatotypes of the participants as a result of anthropometric measurements (Heath \& Carter, 1967). Endomorphy is determined by the roundness and softness of the body. It shows the fatness and fat mass in the organism. The features of this type are short neck, high square shoulders and the sagging of the abdomen over the body. Mesomorphy is determined by stiffness and noticeable muscularity, and the bones surrounded by large and thick muscles. Shoulders are wide and the body is usually above. The outstanding features of this type are the thickness of the forearm, the large size of the hands, wrists and fingers. Ectomorphy is determined by thinness, delicacy and fragile appearance. The bones are small and the muscles are thin. The shoulders are low, the arms and legs are long but the body is short. The shoulders are narrow, and the muscle ratio is low (Gunay, Tamer, \& Cicioglu, 2013; Heath \& Carter, 1967; Sheldon, 1954).

After obtaining the somatotype rating of the subjects, somatocharts are the best way to analyze the results. For the first time, Sheldon (1954) used Reuleaux Triamlex in 1949 to show somatotype data. Somatochart is a schematic triangle and shows known somatotypes at a two-way boundary. The somatotype of a subject is located in the triangle as a point. Somatochart is divided into three sections because of its three axes. These axes intersect at the center of the triangle. Component grades increase from center to the ends of these axes. However, the extreme values in the three components are written on the ends (Gunay, Tamer, \& Cicioglu, 2013).

It is very important for athletes to know their physical and physiological features in terms of their performance. Therefore, the purpose of this study was to compare the physical and anthropometric features between treaceurs and gymnasts in university students who perform jumping and falling movements very often.

\section{Method}

\subsection{Participants}

This study was carried out with male of twelve volunteer participants, 6 traceurs and 6 gymnasts. Participants were informed about the purpose and method of the study before starting the study. The study included individuals who were older than 18 and were engaged in parkour and gymnast sports for at least two years. The anthropometric measurements of athletes were performed together with the heights and body weights of the athletes. 


\subsection{Data-Collection Tools}

-Height: In anatomical posture, with bare feet, joined heels, head in the frontal plane, overhead level touching the vertex point, while the subject is holding the breath, the heights of the athletes was measured with a stadiometer (Seca, Germany) that has a precision of $0.01 \mathrm{~m}$ and the values were recorded in $\mathrm{cm}$.

-Body Weight: In anatomical posture, with bare feet and only shorts being worn, the body weights of the athletes were measured with a stadiometer (Seca, Germany) that has a precision of $0.01 \mathrm{~m}$ and the values were recorded in $\mathrm{kg}$.

-Skinfold Thickness Measurement: A skinfold caliper (Holtain Ltd. Crymych Uk), which applied a pressure of $10 \mathrm{~g} / \mathrm{sq} \mathrm{mm}$ at each angle, was used to determine the skinfold thicknesses of the athletes. Measurements were taken from determined regions (triceps, biceps, subscapular, iliac crest, supraspinale, abdominal, front calf and medial calf).

-Body Breadth Measurement: The body breadth measurements of the participants were performed with the precision meter in the determined regions (humerus, femur, bistyloid and bimalleolar).

-Body Girth Measurement: The body girth measurements of the participants were performed by the same person from the determined regions (arm relaxed, arm flexed and tensed, waist, gluteal, mid-thigh and calf using a folding steel tape measure with a precision degree of $0.1 \mathrm{~cm}$ ). All measurements were performed on the right side of the participants while they were standing and twice for consistency. Then, the mean values were recorded.

Somatotypes of the participants were determined as a result of anthropometric measurements using the Heath-Carter formula $=\mathrm{X}=($ Triceps ST $)+($ Supraspinale ST $)+($ Subscapula ST $)$

Endomorphy $=0.1451 * X-0.00068 * X^{2}+0.0000014 * X^{3}-0.7182$

Mezomorf $=0.858$ (Humerus bicondylar $)+0.601$ (Femur bicondylar $)+0.188$ (Arm relaxed $)+0.161$ (mid-thigh) $-0,131$ (Height) +4.5

Ektomorphy= PI= boy $(\mathrm{cm}) / 3 \sqrt{ }$ ağırlık $(\mathrm{kg})$,

(0.463 PI - 17.63) + 0.1 (Carter and Heath, 1990),

skeletal muscle mass was determined using the validated Lee (Lee et al., 2000) formula;

Lee Formula $=\mathrm{SM}(\mathrm{kg})=\mathrm{Ht}\left(0.00587 \mathrm{CAG}^{2}+0.00138 \mathrm{CTG}^{2}+0.00574 \mathrm{CCG}^{2}\right)+2.4$ sex $-0.026 \mathrm{x}$ age + race + 4.4

(CAG, corrected arm girth; CTG, corrected thigh girth; CCG, corrected calf girth, sex $=1$ for male and 0 for female, race = 1.6 for Asian, 1.2 for African American, and 0 for white or Hispanic. Height is expressed in m.)

and fat mass was determined using the Yuhasz (Yuhasz, 1974) formula designed for athletes and extremely fit individuals.

Yuhasz Formula $=$ Tricep, Subscapular, Suprailiac, Abdominal, Thigh and Calf

(Body Fat Percent $(\%)=(0.1051 \mathrm{x}$ sum of skinfolds $)+2.585)$.

\subsection{Data Analysis}

SPSS 21 program was used in the statistical analysis of this study. Statistical analysis revealed that the data were not distributed normally when the number of participants was taken into consideration. Therefore, nonparametric tests were performed. The data obtained from the participants, the descriptive features of the participants, the arithmetic means (X), the standard deviations (SD) were analyzed and Mann-Whitney $\mathrm{U}$ test was performed to reveal the difference between groups. At the same time, the normality of the data was also confirmed by Kolmogorov-Smirnov test $(\mathrm{p}<0.05)$.

\section{Results}

The descriptive statistics of the participants were presented in Table 1. 
Table 1. Descriptive features of participants

\begin{tabular}{lll}
\hline & Traceurs $(\mathrm{n}=6)$ & Gymnasts $(\mathrm{n}=6)$ \\
\hline Age $($ years $)$ & $18.67 \pm 1.03$ & $19.33 \pm 1.21$ \\
Height $(\mathrm{cm})$ & $172.67 \pm 3.78$ & $175.83 \pm 6.18$ \\
Body Weight $(\mathrm{kg})$ & $62.5 \pm 8.94$ & $65.17 \pm 8.06$ \\
BMI kg/m & $20.98 \pm 2.97$ & $21.11 \pm 2.67$ \\
\hline
\end{tabular}

Note. Kg: Kilogram, cm: Centimeter, m: Meter, BMI: Body Mass Index.

The mean age of the traceurs was $18.67 \pm 1.03$ years, $172.67 \pm 3.78 \mathrm{~cm}$, body weight $62.5 \pm 8.94 \mathrm{~kg}$ and BMI was $20.98 \pm 2.97 \mathrm{~kg} / \mathrm{m}^{2}$. The mean age of the gymnasts was $19.33 \pm 1.21$ years, $175.83 \pm 6.18 \mathrm{~cm}$, body weight $65.17 \pm 8.06 \mathrm{~kg}$ and BMI was $21.11 \pm 2.67 \mathrm{~kg} / \mathrm{m}^{2}$. The body compositions and anthropometric features of the participants were presented in Table 2 below.

Table 2. Body compositions and anthropometric features of participants (Mean \pm SD)

\begin{tabular}{llll}
\hline & Traceurs $(\mathrm{n}=6)$ & Gymnasts $(\mathrm{n}=6)$ & Total $(\mathrm{n}=12)$ \\
\hline Heigth $(\mathrm{cm})$ & $172.67 \pm 3.78$ & $175.83 \pm 6.18$ & $174.25 \pm 5.15$ \\
Weight $(\mathrm{kg})$ & $62.5 \pm 8.94$ & $65.17 \pm 8.06$ & $63.83 \pm 8.23$ \\
Triceps Skinfold (mm) & $7.45 \pm 1.49$ & $8.73 \pm 2.37$ & $8.09 \pm 2$ \\
Biceps Skinfold (mm) & $5.5 \pm 2.04$ & $4.73 \pm .86$ & $5.12 \pm 1.54$ \\
Subscapular Skinfold (mm) & $9.83 \pm 1.25$ & $10.1 \pm .41$ & $9.97 \pm .9$ \\
Iliac Crest Skinfold (mm) & $9.53 \pm 1.54$ & $9.27 \pm .65$ & $9.4 \pm 1.14$ \\
Supraspinal Skinfold (mm) & $6.33 \pm 1.42$ & $6.2 \pm 1.36$ & $6.27 \pm 1.33$ \\
Abdominal Skinfold (mm) & $9.35 \pm 1.2$ & $8.23 \pm .87$ & $8.79 \pm 1.16$ \\
Front Thigh Skinfold (mm) & $10.07 \pm .73$ & $9.83 \pm 2.25$ & $9.95 \pm 1.6$ \\
Medial Calf Skinfold (mm) & $9.57 \pm .64$ & $7.07 \pm 1.99$ & $8.32 \pm 1.92$ \\
Arm Relaxed Girth (cm) & $27.4 \pm 4.07$ & $27.73 \pm 2.78$ & $27.57 \pm 3.33$ \\
Flexed Arm Girth (cm) & $29.78 \pm 4.19$ & $29.87 \pm 3$ & $29.83 \pm 3.48$ \\
Waist Girth (cm) & $77.82 \pm 4.93$ & $71.6 \pm 6.71$ & $77.7 \pm 5.61$ \\
Gluteal Girth (cm) & $89.03 \pm 6.28$ & $90.47 \pm 5.16$ & $89.75 \pm 5.53$ \\
Calf Girth (cm) & $34.4 \pm 2.95$ & $35.85 \pm 2.49$ & $35.13 \pm 2.71$ \\
Mid Thigh Girth (cm) & $51.17 \pm 5.11$ & $50.43 \pm 4.76$ & $50.80 \pm 4.72$ \\
Humerus Breadth (cm) & $6.75 \pm .36$ & $7.15 \pm .81$ & $6.95 \pm .63$ \\
Bistyloid Breadth (cm) & $6.35 \pm .49$ & $6.28 \pm .35$ & $6.32 \pm .41$ \\
Femur Breadth (cm) & $10.1 \pm .55$ & $9.97 \pm .35$ & $10.03 \pm .45$ \\
Bimalleolar Breadth (cm) & $8.07 \pm .52$ & $7.42 \pm .45$ & $7.74 \pm .57$ \\
Endomorphy & $2.70 \pm 0.32$ & $2.90 \pm 0.48$ & $2.80 \pm 0.41$ \\
Mesomorphy & $4.09 \pm 1.70$ & $3.83 \pm 1.51$ & $3.96 \pm 1.54$ \\
Ectomorphy & $3.39 \pm 1.67$ & $3.49 \pm 1.52$ & $3.44 \pm 1.52$ \\
Body Fat Mass \% & $8.45 \pm 0.40$ & $8.18 \pm 0.53$ & $8.31 \pm 0.47$ \\
Body Muscle Mass \% & $32.15 \pm 5.25$ & $33.52 \pm 4.28$ & $32.83 \pm 4.62$ \\
\hline
\end{tabular}

Note. ${ }^{*} \mathrm{P}<0.05$.

There was no significant difference between the participants' skinfold thickness, breadth and girth measurements. $(p<0.05)$. There was no significant difference between the muscle mass and fat percentage of the two groups. It can be said that the dominant somatotype structure between the groups and within the groups is mesomorphy and ectomorphy in the traceurs and gymnasts $(\mathrm{p}<0.05)$. In other words, traceurs mesomorphy gymnasts have ectomorphy structure.

After the somatotype grading of the subjects, the best way to analyze the results is somato-charts. The somato card of the participants is presented in Figure 1. 


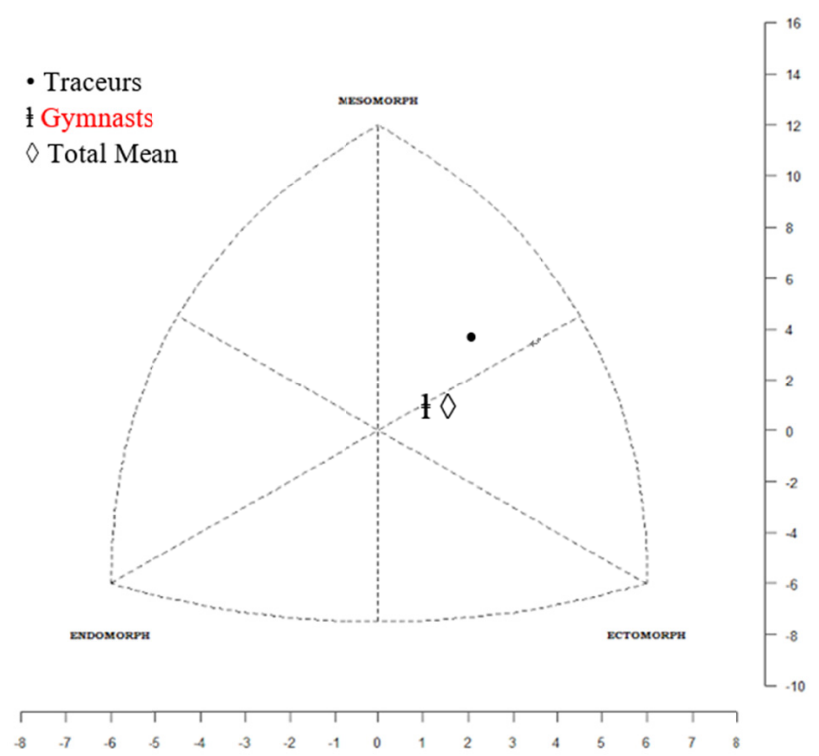

Figure 1. Somato-chart of participants

\section{Discussion and Conclusion}

Nowadays, it is known that many athletes are open to the knowledge and experience that can contribute positively to their athletic performance. It is very important for athletes to know their physical and physiological features in terms of their performance. In the literature, there are a lot of studies on athletes engaged in other sports branches, while there are few studies on traceurs. Therefore, the purpose of this study was to compare the physical and anthropometric features of the traceurs with the gymnasts who perform jumping and falling movements very often. The descriptive statistics of the participants, the mean age of the traceurs was $18.67 \pm 1.03$ years, $172.67 \pm 3.78 \mathrm{~cm}$, body weight $62.5 \pm 8.94 \mathrm{~kg}$ and BMI was $20.98 \pm 2.97 \mathrm{~kg} / \mathrm{m}^{2}$. The mean age of the gymnastics athletes was $19.33 \pm 1.21$ years, $175.83 \pm 6.18 \mathrm{~cm}$, body weight $65.17 \pm 8.06 \mathrm{~kg}$ and BMI was $21.11 \pm 2.67 \mathrm{~kg} / \mathrm{m}^{2}$.

It was observed that the measurements of skinfold thickness, body breadth and girth of all athletes participating in the study did not show a significant difference when compared between the groups. In the body composition evaluation of male gymnasts, lean muscle mass was found to be $33.08 \pm 3.53 \mathrm{~kg}$. At the same time, the mean fat mass of the participants was $7.44 \pm 1.57 \mathrm{~kg}$, the mean fat free mass was $57.74 \pm 5.78 \mathrm{~kg}$, and the final percent body fat was $11.39 \pm 2.08 \%$ (Joao \& Filho, 2015). It can be said that these results show similar results with the previous studies (Heller et al., 1998; Carvalho et al., 2016). There are body structure values related to various sports branches in the literature. In a study, body structures of gymnasts were examined and percent body fat were determined as 5.96\% (Ozer, Pinar, \& Tavacioglu, 1992). In their study with on traceurs, determined the percent body fat of the male athletes as $8.13 \%$ (Abellan \& Alacid, 2016). In another study, percent body fat gymnasts was found to be $7.13 \%$ (Rodriguez, Arturo, Santana, \& Bedoya, 2010). In the present study, according to the data obtained, the percent body muscle of the traceurs and gymnasts was $32.15 \pm 5.25 \%$ and $33.52 \pm$ $4.28 \%$, respectively. On the other hand, their percent body fat was determined as $8.45 \pm 0.40 \%$ (traceurs) and $8.18 \pm 0.53 \%$ (gymnasts) (Yuhasz, 1974).

It can be said that these results show similar results with the previous studies (Arriaza et al., 2016). In a study on the somatotype features of male gymnasts, the somatotype features of these athletes were determined as endomorphy (4.81), mesomorphy (4.81) and ectomorphy (3.07), respectively (Ozer, Pinar, \& Tavacioğlu, 1992). In a study on the somatotype features of tracers, the somatotype features of these athletes were determined as endomorphy (2), mesomorphy (4.07) and ectomorphy (2.7) (Abellan \& Alacid, 2016). In another study, the gymnasts of male were (2.1), (4.5), (2.8) ectomorphy mesomorphy (Penggalih et al., 2016). In this study, according to the data obtained from traceurs and gymnasts, the somatotype features were endomorphy (2.70 \pm 0.32$)$, mesomorphy ( $4.09 \pm 1.70)$ and ectomorphy (3.39 \pm 1.67$)$, and endomorphy ( $2.90 \pm 0.48)$, mesomorphy (3.83 \pm 1.51$)$ and ectomorphy (3.49 \pm 1.52$)$, respectively. It can be said that the dominant somatotype structures between the groups and within groups are mesomorphy and ectomorphy in the traceurs and gymnasts. When 
somatotype features were compared between groups, no significant difference was observed. It is noteworthy that both branches have similar body structures.

In conclusion, learning of these body structure features that determine and affect the performance by coaches education of athletes that athletes will show that perform successfully only with appropriate body structures and coaches may enable the preparation of a better training program. Also the following studies it is thought that the data to be obtained with the high number of participants will make significant contributions to traceurs and gymnasts.

\section{References}

Abellan, A. O., \& Alacid, F. (2016). Anthropometric Profile, Physical Fitness and Differences between Performance Levels of Parkour Practitioners. Archivos de Medicina Del Deporte, 33(5), 312-316.

Arriaza, E., Rodriguez, C., Carrasco, C., Mardones, C., Niedmann, L., \& Lopez-Fuenzalida, A. (2016). Anthropometric Characteristics of Elite Rhythmic Gymnasts. International Journal of Morphology, 34(1), 17-22. https://doi.org/10.4067/S0717-95022016000100003

Carter, J. E. L., \& Heath, B. H. (1990). Somatotyping-Development and Applications. Cambridge: Cambridge University Press.

Carvalho, L. A., Klentrou, P., da Luz Palomero, M., \& Lebre, E. (2016). Body Composition Profile of Elite Group Rhythmic Gymnasts. Science of Gymnastics Journal, 4(1), 21-32.

Claessens, A. L., Lefevre, J., Beunen, G., Maes, M., \& Stijnen, V. (1999). The Contribution of Anthropometric Characteristics to Performance Scores in Elite Female Gymnasts. The Journal of Sports Medicine and Physical Fitness, 39, 355-360.

Grosprete, S., Ufland, P., \& Jecker, D. (2017). The Adaptation to Standing Long Jump Distance in Parkour is Performed by the Modulation of Specific Variables Prior and During Take-Off. Movement \& Sport Sciences - Science \& Motricité, 27-37. https://doi.org/10.1051/sm/2017022

Grospretre, S., \& Lepers, R. (2016). Performance Characteristics of Parkour Practitioners: Who Are the Traceurs? European Journal of Sport Science, 16(5), 526-535. https://doi.org/10.1080/17461391.2015.1060263

Gunay, M., Tamer, K., \& Cicioglu, İ. (2013). Sports Physiology and Performance Measurement. Gazi Bookstore, 3,579 .

Heath, B. H., \& Carter, J. E. L. (1967). A Modified Somatotype Method. American Journal of Physical Anthropometry, 27(1), 57-74. https://doi.org/10.1002/ajpa.1330270108

Heller, J., Tuma, Z., Dlouha, R., Bunc, V., \& Novakova, H. (1998). Anaerobic Capacity in Elite Male and Female Gymnasts. Acta Universitatis Carolinae-Kinanthropologica, 34(2).

Hume, P. A., Hopkins, W. G., Robinson, D. M, Robinson, S. M., \& Hollings, S. C. (1993). Predictors of Attainment in Rhythmic Sportive Gymnastics. The Journal of Sports Medicine and Physical Fitness, 33(4), 367-377.

Joao, A. F., \& Filho, J. F. (2015). Somatotype and Body Composition of Elıte Brazllıan Gymnasts. Science of Gymnastics Journal, 7(2), 45-54.

Kaynar, O., Seyhan, S., \& Bilici, M. F. (2018). Investigation of Factors Affecting Sportive Success in Wrestlers. Ataturk University Journal of Physical Education and Sports Sciences, 20(1), 54-59.

Lee, R. C., Wang, Z., Heo, M., Ross, R., Janssen, I., \& Heymsfield, S. B. (2000). Total-Body Skeletal Muscle Mass: Development and Cross-Validation of Anthropometric Prediction Models. American Journal Clinical Nutrition, 72(3), 796-803. https://doi.org/10.1093/ajen/72.3.796

Mala, L., Maly, T., Zahalka, F., Bunc, V., Kaplan, A., Jebavy, R., \& Tuma, M. (2015). Body Composition of Elite Female Players in Five Different Sports Games. $J$ Hum Kin, 45, 207-215. https://doi.org/10.1515/hukin-2015-0021

Marta, C. C., Marinho, D. A., Barbosa, T. M., Carneiro, A. L., Izquierdo, M., \& Marques, M. C. (2013). Effects of Body Fat and Dominant Somatotype on Explosive Strength and Aerobic Capacity Trainability in Prepubescent Children. The Journal of Strength and Conditioning Research, 27, 3233-3244. https://doi.org/10.1519/JSC.0000000000000252 
Misigoj-Durakovic, M. (2012). Anthropometry in Premenarcheal Female Esthetic Sports Athletes and Ballerinas. In V. R. Preedy (Ed.), Handbook of Anthropometry (pp. 1817-1836). New York: Springer. https://doi.org/10.1007/978-1-4419-1788-1_111

Moreno, G. A., Moreno, L. E. A., \& Jaramillo, P. C. A. (2011). Characterization of Karate Athletes and College Basketball: Body Composition and Anthropometry Saltability. Rev. Edu-Fisica, 3(8), 1-20.

Munoz-Cachon, J. M., Salces, I., Arroyo, M., Ansotegui, L., Rocandio, M. A., \& Rebato, E. (2007). Body Shape and S.E.S. in Young Adults. Collegium Antropologicum, 31(4), 963-968.

Ozer, K., Pinar, S., \& Tavacioglu, L. (1992). Anthropometric Features of Elite Young Male Gymnasts. National Congress Proceedings (p. 243), H. Ü. School of Sports Sciences and Technology, Ankara.

Ozer M., K. (2009). Kinantropometri: Sporda Morfolojik Planlama. Nobel Yayın Dağıtım, 47-62. Ankara.

Ozkan, A., Koklu, Y., \& Ersoz, G. (2010). Anaerobic Performance and Measurement Methods (1st ed., pp. 317). Ankara, Gazi Bookstore.

Penggalih, T. S. H. M., Narruti, H. N., Fitria, F., Pratiwi, D., Sari, P. D. M., Winata, N. F., \& Kusumawati, M. D. (2016). Identification of Somatotype, Nutritional Status, Food and Fluid Intake in Gymnastics Youth Athletes. Asia Pacific Journal of Clinical Nutrition, 8(1-3), 1-8. https://doi.org/10.3923/ajcn.2016.1.8

Rodriguez, L., Arturo, G., Santana, M. V., \& Bedoya, J. L. (2010). Somatotype and Body Composition in Elite Male Spanish Trampoline. Rev Int Cienc Deporte, 6(19), 141-153.

Sheldon, W. (1954). Atlas of Men. New-York: Harper and Brothers.

Slater, G., O'Connor, H., \& Kerr, A. (2017). Optimising Physique for Sports Performance. Best Practice Protocols for Physique Assessment in Sport, 27-36.

Thomson, D. (2008). Jump City. Parkour and the Traces. South Atlantic Quarterly, 107, 251-263. https://doi.org/10.1215/00382876-2007-065

Vila, H., Ferragut, C., Argudo, F. M., Abraldes, J. A., Rodrıuez, N., \& Alacid, F. (2009). Relationship between anthropometric parameters and throwing velocity in water polo players. Journal of Human Sport and Exercise, 4, 57-68. https://doi.org/10.4100/jhse.2009.41.07

Yıldız, S. (2018). Relationship between Functional Movement Screen and Some Athletic Abilities in Karate Athletes. Journal of Education and Training Studies, 6(8), 66-69. https://doi.org/10.11114/jets.v6i8.3352

Yuhasz, M. S. (1974). Physical Fitness Manual (p. 62). University of Western Ontario.

\section{Copyrights}

Copyright for this article is retained by the author, with first publication rights granted to the journal.

This is an open-access article distributed under the terms and conditions of the Creative Commons Attribution license (http://creativecommons.org/licenses/by/4.0/). 